\begin{tabular}{|c|c|c|}
\hline \multirow{3}{*}{$\begin{array}{l}\text { EREM 73/4 } \\
\text { Journal of Environmental Research, } \\
\text { Engineering and Management } \\
\text { Vol. } 73 \text { / No. } 4 \text { / } 2017 \\
\text { pp. 21-30 } \\
\text { DOl 10.5755/j01.erem.73.4.19316 } \\
\text { @ Kaunas University of Technology }\end{array}$} & \multicolumn{2}{|c|}{$\begin{array}{c}\text { Exposure to Total Volatile Organic Compounds from } \\
\text { Household Spray Products }\end{array}$} \\
\hline & Received 2017/10 & Accepted after revision $2017 / 11$ \\
\hline & \multicolumn{2}{|c|}{ crossef http://dx.doi.org/10.5755/j01.erem.73.4.19316 } \\
\hline
\end{tabular}

\title{
Exposure to Total Volatile Organic Compounds from Household Spray Products
}

\author{
ADENIRAN, Jamiu Adetayo, YUSUF, Rafiu Olasunkanmi, MUSTAPHA, Sherif Ishola \\ Environmental Engineering Research Laboratory, Department of Chemical Engineering, University of Ilorin, llorin, Nigeria
}

\section{SONIBARE, Jacob Ademola}

Environmental Engineering Research Laboratory, Department of Chemical Engineering, Obafemi Awolowo University, Ile-Ife, Nigeria

Corresponding author: adeniran.ja@unilorin.edu.ng

Environmental Engineering Research Laboratory, Department of Chemical Engineering, University of Ilorin, llorin, Nigeria

Emission of volatile organic compounds from the use of household spray products has a negative impact on health and environment. Total volatile organic compound (TVOC) concentration levels emitted from 45 registered consumer spray products in Nigeria were measured using the MultiRAE TVOCs gas monitor. Human exposure to emitted TVOCs through inhalation, ingestion or through the dermal route was evaluated using the ConsExpo spray model. The average TVOCs emission from all the investigated samples was in the range of 1,664 and $560,994.7 \mu \mathrm{g} \mathrm{m}^{-3}$ with an average of $63,632.2 \mu \mathrm{g} \mathrm{m}^{-3}$. Generally for all the samples considered, the average released concentrations, the inhaled doses, the dermal doses, and the average deposition rates values obtained were in the ranges of $1.83 \mathrm{E}+04-1.00 \mathrm{E}+06 \mu \mathrm{g} \mathrm{m} \mathrm{m}^{-3} ; 1.47 \mathrm{E}+03-8.01 \mathrm{E}+04 \mu \mathrm{g} ; 3.41 \mathrm{E}+04-4.84 \mathrm{E}+05 \mu \mathrm{g}$; and $1.79 \mathrm{E}+01-1.01 \mathrm{E}+03 \mu \mathrm{g} \mathrm{s}^{-1}$, respectively. The results provide information that could be used to significantly improve human exposure and risk assessment to emitted aerosols from spray products.

Keywords: household products, exposure, total volatile organic compounds, hazard ratio, indoor environment.

\section{Introduction}

People use household spray products in indoor environments where they spend a higher percentage of their time. The use of household spray products results in introduction and elevation of volatile organic 
compound levels in the indoor environment (Adeniran, Sonibare, \& Jimoda, 2015). VOCs have been widely studied and they have been reported to contribute to human health deterioration and depletion of ozone in the atmosphere (Dinh et al., 2015). A number of spray products contain VOCs in the form of fragrances, propellants, and other active ingredients. Some of the undisclosed constituents of the total volatile organic compounds present in household products have been classified as toxic and hazardous under federal laws of most developed countries (Steinemann, 2009).

Human exposure to emitted VOCs can occur through inhalation, ingestion or through the dermal route. The aim of this study is to quantify the concentration levels of TVOCs emitted from consumer spray products and estimate their exposure level.

\section{Methodology}

\section{Mass generation rates}

Average mass generation rates of household spray products were determined by averaging mass of aerosol released for 3 scenarios (full filled, half-filled and while almost empty). In each case, an individual spray product was weighed using Mettle Toledo weighing balance to obtain the initial weight, sprayed for 10 seconds and reweighed to obtain the final weight. The mass generated for each case was determined using equation 1

$$
M_{g}=\frac{M_{i}-M_{f}}{t}
$$

where $M_{g}$ is the mass generation rate, $M_{i}(g)$ is the initial weight of the sample, $M_{f}(g)$ is the final weight of the sample and $\mathrm{t}$ is the time $(\mathrm{s})$.

A wide range of consumer products was sampled in order to fully capture the behaviour of aerosols being investigated. Forty-five (45) commercially available household spray products in the Nigerian market were considered for investigation. The selected samples include: 15 different brands of air fresheners, 15 different brands of insecticides, 5 different brands of hairsprays, 5 different brands of perfumes, 2 different brands of shoe impregnation sprays and 3 different brands of surface polish (Table 1). Production dates on the selected samples suggested that they had been manufactured not more than 3 months before they were used for the study. Since specific information on

\section{Table 1}

Characteristics of household products used in the study

\begin{tabular}{c|c|c|c|c|l}
\hline S/N & Product & Product type & Use category & Filling level $(\mathrm{ml})$ & \multicolumn{1}{|c}{ Major listed ingredients } \\
\hline 1 & 2 & 3 & 4 & 5 & 6 \\
\hline 1 & INST A & Insecticide & Air space & 300 & Butane, propane, active ingredients \\
\hline 2 & INST B & Insecticide & Air space & 300 & Butane, propane, active ingredients \\
\hline 3 & INST C & Insecticide & Air space & 300 & Butane, propane, active ingredients \\
\hline 4 & INST D & Insecticide & Air space & 300 & Butane, propane, active ingredients \\
\hline 5 & INST E & Insecticide & Air space & 400 & Butane, propane, active ingredients \\
\hline 6 & INST F & Insecticide & Air space & 330 & Isobutane, propane, active ingredients \\
\hline 7 & INST G & Insecticide & Air space & 300 & Butane, propane, active ingredients \\
\hline 8 & INST H & Insecticide & Air space & 300 & Isobutane, propane, active ingredients \\
\hline 9 & INST I & Insecticide & Air space & 300 & Butane, propane, active ingredients \\
\hline 10 & INST J & Insecticide & Air space & 400 & Butane, propane, active ingredients \\
\hline 11 & INST K & Insecticide & Air space & 400 & Butane, propane, active ingredients \\
\hline 12 & INST L & Insecticide & Air space & 300 & Butane, propane, active ingredients \\
\hline 13 & INST M & Insecticide & Air space & 305 & Butane, propane, active ingredients \\
\hline
\end{tabular}




\begin{tabular}{|c|c|c|c|c|c|}
\hline 1 & 2 & 3 & 4 & 5 & 6 \\
\hline 14 & INST N & Insecticide & Air space & 300 & Butane, propane, active ingredients \\
\hline 15 & INST 0 & Insecticide & Air space & 600 & Butane, propane, water, active ingredients \\
\hline 16 & AFN A & Air freshener & Air space & 300 & $\begin{array}{l}\text { Butane, propane, ethane, 1,1-difluoro-, } \\
\text { fragrances }\end{array}$ \\
\hline 17 & AFN B & Air freshener & Air space & 300 & Butane, propane, active ingredients \\
\hline 18 & AFN C & Air freshener & Air space & 300 & Butane, propane, active ingredients \\
\hline 19 & AFN D & Air freshener & Air space & 300 & Butane, propane, active ingredients \\
\hline 20 & AFNE & Air freshener & Air space & 300 & Butane, propane, active ingredients \\
\hline 21 & AFN F & Air freshener & Air space & 400 & Butane, dimethyl ether, fragrances \\
\hline 22 & AFN G & Air freshener & Air space & 400 & Butane, propane, active ingredients \\
\hline 23 & AFN H & Air freshener & Air space & 500 & Butane, isobutane, propane, fragrances \\
\hline 24 & AFN I & Air freshener & Air space & 300 & $\begin{array}{l}\text { Butane, propane, disodium tetraborate } \\
\text { decahydrate, fragrances }\end{array}$ \\
\hline 25 & AFN J & Air freshener & Air space & 300 & Butane, propane, active ingredients \\
\hline 26 & AFN K & Air freshener & Air space & 400 & Butane, propane, active ingredients \\
\hline 27 & AFN L & Air freshener & Air space & 500 & Butane, propane, active ingredients \\
\hline 28 & AFN M & Air freshener & Air space & 320 & $\begin{array}{l}\text { 1,1-difluoroethane, propane, terpenes and } \\
\text { terpenoids, sweet orange-oil }\end{array}$ \\
\hline 29 & AFN N & Air freshener & Air space & 300 & Butane, propane, fragrances \\
\hline 30 & AFN 0 & Air freshener & Air space & 330 & Butane, propane, fragrances \\
\hline 31 & PEF A & Perfume/body spray & Towards person & 75 & Isobutane, propane, fragrances \\
\hline 32 & PEF B & Perfume/body spray & Towards person & 75 & Isobutane, propane, fragrances \\
\hline 33 & PEFC & Perfume/body spray & Towards person & 200 & Isobutane, propane, fragrances \\
\hline 34 & PEF D & Perfume/body spray & Towards person & 110 & Isobutane, propane, fragrances \\
\hline 35 & PEF E & Perfume/body spray & Towards person & 75 & Isobutane, propane, fragrances \\
\hline 36 & HSP A & Hair spray & Towards person & 450 & Propylene glycol, isopropyl alcohol \\
\hline 37 & HSP B & Hair spray & Towards person & 450 & $\begin{array}{l}\text { 1,1-difluoroethane, ethanol, methoxyethene, } \\
\text { proprietary fragrance }\end{array}$ \\
\hline 38 & HSP C & Hair spray & Towards person & 450 & $\begin{array}{l}\text { Dimethyl ether, methacrylate co-polymer, } \\
\text { butylene glycol, sodium benzoate }\end{array}$ \\
\hline 39 & HSP D & Hair spray & Towards person & 625 & Dimethyl ether, sd alcohol 40-b (ethanol) \\
\hline 40 & HSPE & Hair spray & Towards person & 450 & Ethyl alcohol, propane, butane \\
\hline 41 & SPLA & Surface polish & Surface & 300 & Acetone, n-butane, propane \\
\hline 42 & SPL B & Surface polish & Surface & 250 & $\begin{array}{l}\text { White mineral oil, petroleum, distillates } \\
\text { (petroleum), hydrotreated light }\end{array}$ \\
\hline 43 & SPLC & Surface polish & Surface & 300 & Ethanol, 2-butoxy, isopropyl alcohol \\
\hline 44 & SSP A & Shoe impregnation spray & Surface & 220 & $\begin{array}{l}\text { 1,1,1,2-tetrafluoroethane R134A, dimethyl } \\
\text { ether }\end{array}$ \\
\hline 45 & SSP B & Shoe impregnation spray & Surface & 200 & $\begin{array}{l}\text { Hydrotreated light distillate, mineral spirits, } \\
\text { aromatic petroleum distillates }\end{array}$ \\
\hline
\end{tabular}


the products' comprehensive description and ingredients is rare, the criterion for product selection was the packaging label, which indicates they are aerosolized products. The ingredients list on the labels of most samples selected indicates that they contain the active ingredients and the propellants that account for between $60 \%$ and $90 \%$ of their total volume. The active ingredients in fragranced products were simply termed 'fragrance'. The most common propellants listed and declared for the selected samples include butane, isobutane and propane.

\section{Sampling procedure}

TVOCs measurements were done using the MultiRAE Gas Monitor (Model PGM50-5P), manufactured by RAE Systems Inc., USA. The monitor is a $9.3 \mathrm{~cm}$ $\times 4.9 \mathrm{~cm} \times 2.2 \mathrm{~cm}$ measuring instrument weighing about $0.1 \mathrm{~kg}$ with an instantaneous direct readout display through which VOCs concentrations can be continuously monitored in ppm (parts per million). It has a detection range of between $0-200 \mathrm{ppm}$ with $0.1 \mathrm{ppm}$ resolution. It has a facility for short term exposure limit (STEL) from which TVOC concentration for the last 15 minutes can be determined; the time weighted average (TWA) from which the accumulated reading of the TVOC concentration was turned on divided by 8 hours; and the peak reading, which will represent the highest concentration. Each of the aerosol spray products was sprayed for 10 seconds inside the experimental room. Average microclimatic parameters in the experimental room were $55 \%, 32.0^{\circ} \mathrm{C}$ and $9 \mathrm{~h}^{-1}$ for relative humidity, temperature and air exchange rate, respectively. Sprays produced by the aerosol products were characterized by the methods proposed by Fédération Européenne Des Aérosols (FEA, 2009). The TVOC sampler was placed at $40 \mathrm{~cm}$ above the spraying nozzle or the receptor. The position depends on the protocol that was employed for different spray product categories. Measurements were taken 15 times for each product and averaged ( 5 each for fully filled, half-filled and almost empty).

\section{Exposure assessment}

The hazard ratio (HR) and ConsExpo spray model approaches were used to assess the risks associated with the use of spray products. The concentration levels obtained were compared with some of the existing air quality standards for TVOCs. Hazard ratio was determined as the ratio of the measured to that of the statutory limits such as the limits of the Nigerian Federal Ministry of Environment, the World Health Organization and literature established TVOCs guidelines (FEPA, 1991; Mølhave \& Nielsen, 1992; WHO, 2010; Zabiegała, 2006).

The ConsExpo spray model used was developed by the National Institute for Public Health and the Environment (RIVM), Netherlands. It was used to evaluate human exposure to aerosol released from the spraying activities in the experimental room. ConsExpo has been used internationally to assess the exposure of consumers to substances in consumer products (Bremmer, Prud'Homme de Lodder, \& Van Engelen, 2006; Rothe et al., 2011). The main input parameters for the model are the released droplet spectrum, the release rate, the concentration of the pollutant, the spatial and temporal pattern of the release process (surface spraying against floor, ceiling, wall, room spraying), the vapour pressure of the liquid, the size of the room and the ventilation rate. The main output parameters are the concentration calculated values, the concentration versus time diagram and the time-integrated inhaled and deposited dose of the pollutants considered. The model is based on assumptions that the sprayed product is composed of a non-volatile substance dissolved in a solvent with known volatility, and the determination of the inhaled dose is based on the International Conventions on Health-Related Particle Sampling defined for example in CEN481.

\section{Results and discussion}

\section{Mass generation rates}

The mass generation rates of the 45 different household spraying product samples selected for investigation were determined and results were presented in Fig. 1. For the insecticide samples considered, INST A has the highest mass generation rate of $4.37 \mathrm{~g} / \mathrm{s}$, while INST $F$ has the least mass generation rate of $1.28 \mathrm{~g} / \mathrm{s}$. The mean aerosol mass generation rate for the insecticides is $2.56 \mathrm{~g} / \mathrm{s}$ with the standard deviation 
Fig. 1

Mass generation rates of aerosols from spray products

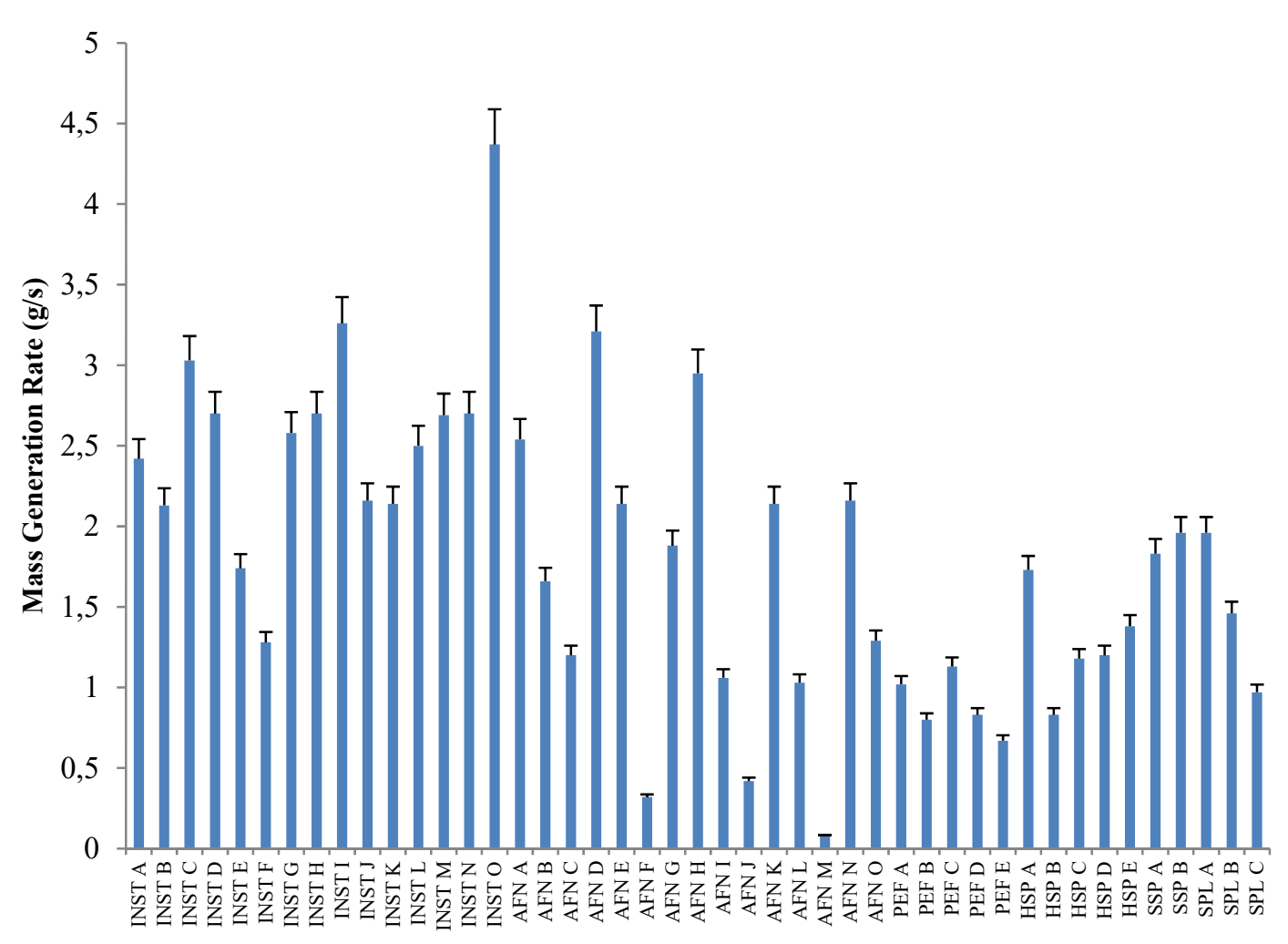

Samples

of $0.7 \mathrm{~g} / \mathrm{s}$. The mass generation rate for air freshener samples ranged from 0.08 to $3.21 \mathrm{~g} / \mathrm{s}$. The mean mass generation rate was $1.61 \mathrm{~g} / \mathrm{s}$ with a standard deviation of $0.94 \mathrm{~g} / \mathrm{s}$. AFN D has the highest mass generation rate, while AFN M has the least mass generation rate. For the perfume samples considered, the mass generation rate ranged from $0.67 \mathrm{~g} / \mathrm{s}$ to $1.13 \mathrm{~g} / \mathrm{s}$ with the mean value of $0.89 \mathrm{~g} / \mathrm{s}$ and the standard deviation of 0.18 . The highest mass generation rate was measured in PEF C and the lowest in PEF E.

\section{Concentration levels of TVOCs in consumer spray products}

The concentrations of the resulting TVOCs were in the range of $173,765.7$ and $17,115.09 \mathrm{~g} \mathrm{~m} \mathrm{~m}^{-3}$ for insecticides. INST L emitted the highest concentration of TVOCs (Fig. 2), and INST O was the least emitter of TVOCs in all the insecticides investigated. The average concentration of TVOCs emission from insecticides was 55,085.24 47,007.51 $\mathrm{mg} \mathrm{m}^{-3}$.

Air freshener samples had a TVOC concentration range of $1,663.97$ and $23,533.25 \mu \mathrm{g} \mathrm{m}^{-3}$. AFN 0 emitted the highest TVOC concentration and AFN L emitted the least. The mean emitted concentration is 7,337.30 $\mu \mathrm{g} \mathrm{m}^{-3}$ with the standard deviation of $5750.04 \mathrm{\mu g} \mathrm{m}^{-3}$.

For perfume, hairspray, surface polish and shoe impregnated spray samples, TVOC emission ranged 2,377.10-87,477.14 $\mathrm{ug} \mathrm{m}^{-3} ; 49,919.02-560,996.98 \mathrm{\mu g} \mathrm{m}^{-3}$; $18,9312.27-441,149.70{\mu ~ m^{-3} \text { and } 118,450.43-161,175.95}$ $\mu \mathrm{g} \mathrm{m}^{-3}$ with respective average concentrations of $61,091.37$ $\mu \mathrm{g} \mathrm{m}^{-3}, 166,254.10 \mu \mathrm{g} \mathrm{m}^{-3}, 281,263.19$ and 139,813.19 $\mu \mathrm{g}$ $\mathrm{m}^{-3}$. In all the hairspray samples considered in this study, HSP A emitted the highest concentration of TVOCs with a concentration of $560,996.98 \mu_{\mathrm{g} \mathrm{m}}^{-3}$. 
Fig. 2

Concentration levels of TVOCs emitted from selected spray products

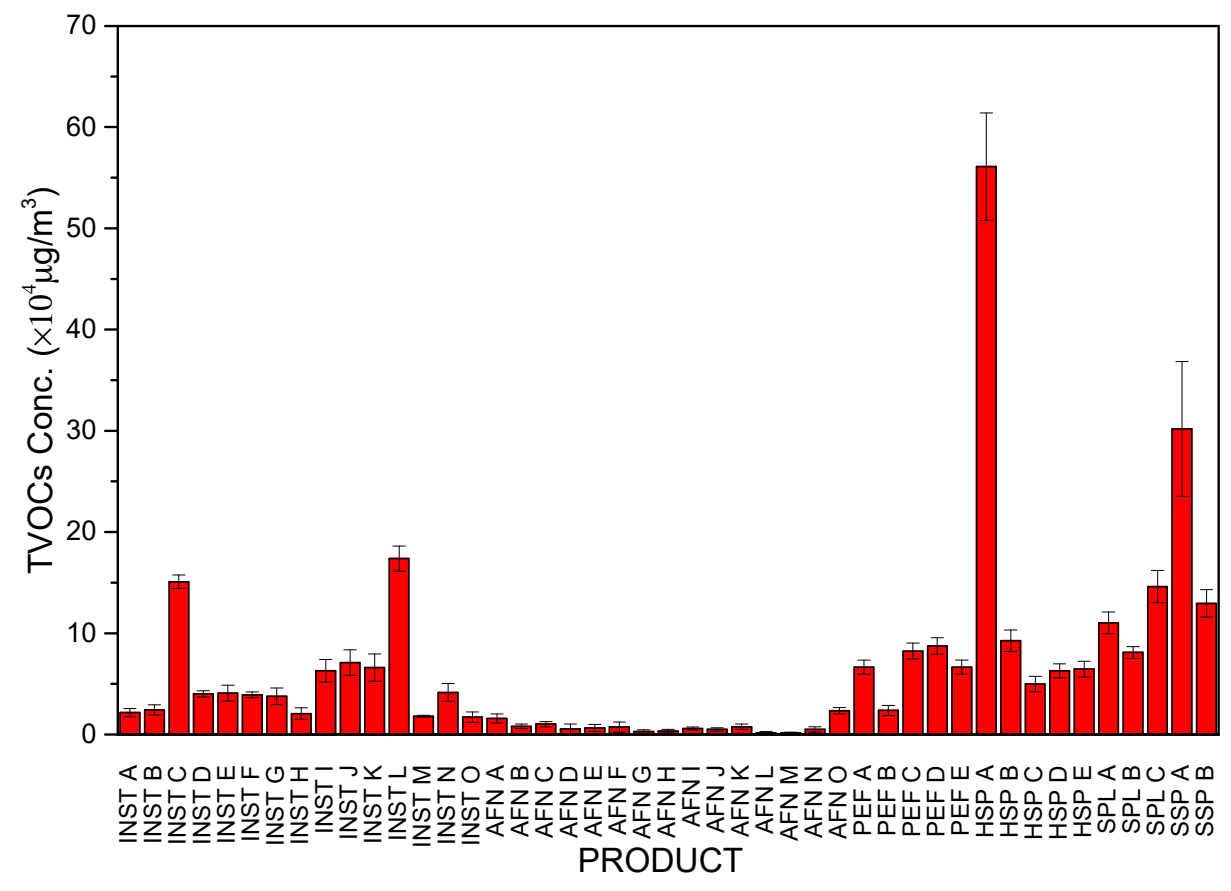

Generally, the average TVOC emission from all the investigated samples was in the range of $1,664 \mathrm{\mu g} \mathrm{m}^{-3}$ and $71,039.59 \mathrm{\mu g} \mathrm{m}^{-3}$ with an average of $50,994.7 \mu \mathrm{g}$ $\mathrm{m}^{-3}$. Mølhave and Nielsen (1992) and Zabiegata (2006) considered TVOC concentration below 200-600 $\mathrm{\mu g} \mathrm{m}^{-3}$ to be within the comfort range, $200-3,000 \mathrm{\mu g} \mathrm{m}^{-3}$ as the multifactoral exposure range which is considered to be a health hazard; $3,000-25,000 \mu \mathrm{g} \mathrm{m}^{-3}$ being the discomfort range that could bring strong discomfort to inhabitants of indoor environment and a concentration greater than $25,000 \mathrm{\mu g} \mathrm{m}^{-3}$ as a toxic range.

The measured concentrations of TVOCs from the samples used are in either the discomfort range or the toxic range. This indicates that occupants are often exposed to hazardous and toxic levels of TVOCs whenever the samples are used in the indoor environment. Also, recent investigations have suggested that TVOC concentrations in consumer spray products fall short of the general regulatory requirements as they were found to be far above the recommended limits (Steinemann, 2009).

\section{Exposure assessment}

\section{Total volatile organic compounds hazard ratios}

TVOC measured and extrapolated readings were compared with the FEPA limit of $1.9 \mathrm{ppm}$ (FEPA, 1991) and the WHO limit of $6.3 \mathrm{ppm}$ (WHO, 2010) for 24 hours measurement to establish the hazard ratio for daily values. Also, TVOC instant/initial values were compared with the limits set by Mølhave and Nielsen (1992) to establish if the instantaneous concentrations would have deleterious challenges for human health.

The HR values for TVOCs for all the samples investigated are summarized in Fig. 3. For insecticide samples, FEPA and WHO 24-hour obtained HR ranges were $0.29-2.77$ and $0.12-1.11$, respectively, while the Mølhave and Nielsen (1992) HR value for instantaneous release was in the range of $0.68-6.95$. The air freshener TVOC HR was in the range of $0.05-0.89$, and $0.02-0.36(0.09 \pm 0.09)$ for the daily FEPA and WHO HR values, respectively. 
For perfumes, FEPA and WHO 24-hour HR values were in the range of 0.11-0.46, and 0.01-0.12, while the Molhave and Nielsen obtained HR values were 0.10-3.50. The computed values for hairsprays FEPA and WHO 24- hour HR values were $0.70-6.80$ and $0.14-0.32$, respectively. Molhave and Nielsen HR value for hairsprays was 2.00-22.44.

Surface sprays and shoe impregnation sprays have the respective Molhave and Nielsen HR levels of the range 4.74-6.45 and 7.57-17.65, respectively. Surface sprays obtained FEPA and WHO 24-hour HR levels ranges were $0.17-0.48$ and $0.05-0.13$, respectively, while their respective levels for shoe impregnation sprays were in the range of 0.5-1.02 and 0.14-0.28.

The FEPA (1991) limit was breached in 53.33\% of the 15 insecticide samples considered. Values close to unity were obtained for $26.7 \%$ of the insecticides samples. When the initial concentrations were compared to Molhave and Nielsen's (1992) standards, higher HR values of the range 0.68 and 6.95 were obtained. Values for 10 insecticides exceeded this limit as 3 other HR values was close to unity.
For air fresheners, none of the statutory set limits were breached as HR values for FEPA, WHO and Molhave and Nielsen (1992) TVOC set limits were below unity. This might be because the propellants used in insecticide manufacture/blending contain more TVOCs than the air freshener samples.

For perfumes, hairsprays, surface polish and shoe impregnation sprays, the initial concentration Molhave and Nielson recommended limits were grossly breached by all the samples except one which is suspected to contain some element of water as part of its composition. One hairspray and one surface polish samples gave higher HR levels of 22.44 and 17.65, respectively. This implies that a very high concentration deleterious to humans may be inhaled during use. Besides, $40 \%$ of hairspray samples and $33.3 \%$ of surface spray samples breached the FEPA 24-hour limit. Also, $20 \%$ of hairspray samples, $33.3 \%$ of shoe impregnation spray samples, and $100 \%$ of surface spray samples breached the WHO limit for 24 hours.

The high instantaneous HR levels obtained in this

Fig. 3

Hazard ratios of TVOCs from spray products

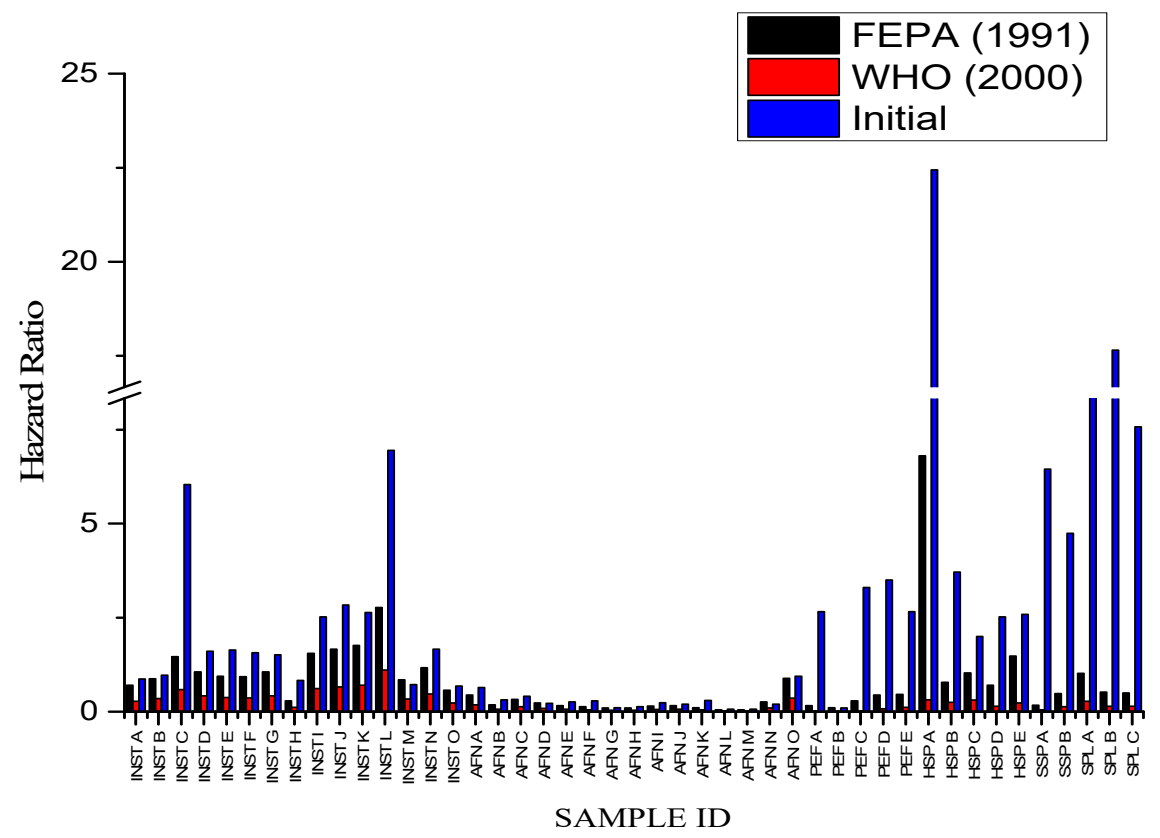


study from the use of consumer spray products could lead to an array of health-related ailments as TVOCs found in household products have been found to be responsible for irritation of the lungs, nausea, headaches, pulmonary diseases, and death (Lakey et al., 2017). Susceptibility to lung cancer and other noncancerous ailments is commonly associated with people frequently exposed to TVOCs in the indoor environment (Norbäck, Hashim, Hashim, \& Ali, 2017).

While environmental and health implications of TVOCs cannot be overemphasized, TVOCs from spray consumer products could contribute to the greenhouse effect, acid rains and stratospheric ozone depletion, which are regarded as environmental problems (Erickson III, Sulzberger, Zepp, \& Austin, 2015). Those emitted from household consumer products could also serve as precursors for the formation of secondary organic aerosols (SOA), which are presumed to be more harmful than primary aerosols (Erickson III et al., 2015). They could readily react with ambient ozone, a hydroxyl group and nitrates to give complex compounds and particulate matter (Erickson III et al., 2015; Romonosky et al., 2017).

\section{ConsExpo spray model results}

For insecticides (Fig. 4), the average concentration was in the range of $2.93 \mathrm{E}+05$ and $1.00 \mathrm{E}+6 \mathrm{\mu g} \mathrm{m}^{-3}$. The inhaled dose from insecticides spraying ranged from $2.35 \mathrm{E}+04$ to $8.01 \mathrm{E}+04 \mu \mathrm{g}$, while the dermal dose was between $1.38 \mathrm{E}+04$ and $4.84 \mathrm{E}+04 \mu \mathrm{g}$ with the respective average deposition between $2.87 \mathrm{E}+02$ and $1.01 \mathrm{E}+03 \mu \mathrm{g} \mathrm{s}^{-1}$.

Average aerosol concentration levels for air freshener spraying (Fig. 4) ranged between $1.83 \mathrm{E}+04$ and $7.35 \mathrm{E}+05 \mu \mathrm{g} \mathrm{m}^{-3}$. The simulated amount inhaled was between $1.47 \mathrm{E}+03$ and $5.88 \mathrm{E}+04 \mu \mathrm{g}$, while the dermal dose ranged between $3.41 \mathrm{E}+04$ and $3.49 \mathrm{E}+05$ $\mu \mathrm{g}$. The average deposition ranged between $1.79 \mathrm{E}+01$ and $7.28 \mathrm{E}+01 \mathrm{\mu g} \mathrm{s}^{-1}$. The average released aerosol concentration for hairspray (Fig. 4) ranged between $1.90 \mathrm{E}+05$ and $3.96 \mathrm{E}+05 \mu \mathrm{g} \mathrm{m}^{-3}$. The averaged inhaled and dermal dose ranges were between 1.52E+04 and $3.17 \mathrm{E}+04 \mu \mathrm{g}$, and between $8.60 \mathrm{E}+04$ and $1.77 \mathrm{E}+05 \mu \mathrm{g}$, respectively. The average deposition range was between 1.79E+02 and 3.69E+02 $\mu_{\mathrm{g} \mathrm{s}}{ }^{-1}$.

\section{Fig. 4}

ConsExpo model exposure assessment results

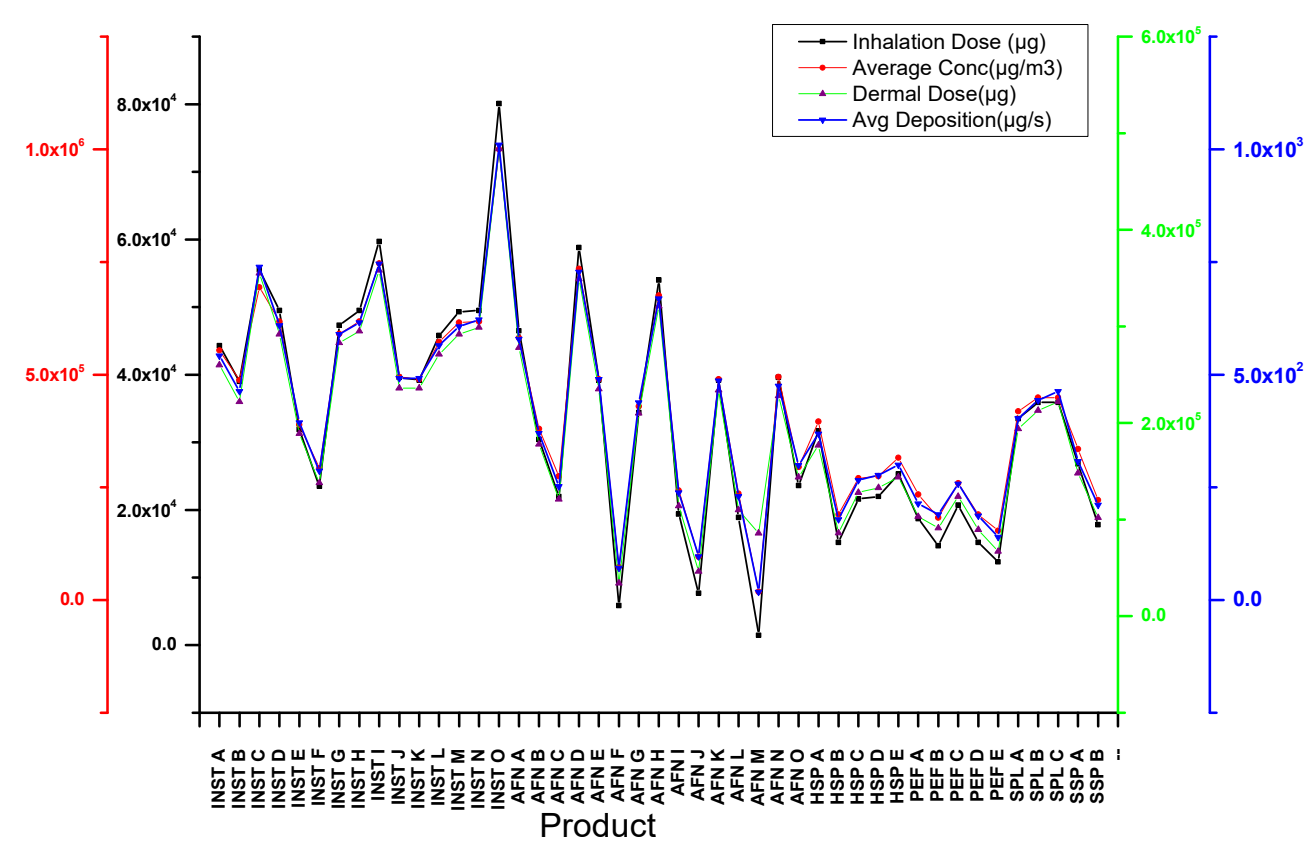


For perfumes, the average released concentration ranges (Fig. 4) were between 1.54E+05 and 2.59E+05 $\mathrm{\mu g} \mathrm{m}^{-3}$, while the inhaled and dermal dose ranges were between $1.23 \mathrm{E}+04$ and $2.07 \mathrm{E}+04 \mu \mathrm{g}$, and between $6.70 \mathrm{E}+04$ and $1.24 \mathrm{E}+05 \mu \mathrm{g}$, respectively. The average deposition rates varied between $1.40 \mathrm{E}+02$ and $2.58 \mathrm{E}+02 \mu \mathrm{g} \mathrm{s}{ }^{-1}$.

For surface polish and shoe impregnation sprays, the average released concentrations (Fig. 4) were in the range of $2.22 \mathrm{E}+05$ and $4.49 \mathrm{E}+05 \mathrm{\mu g} \mathrm{m}^{-3}$, while the inhaled and dermal doses were between $1.78 \mathrm{E}+04$ and $3.59 \mathrm{E}+04 \mu \mathrm{g}$, and between $1.02 \mathrm{E}+05$ and $2.22 \mathrm{E}+05 \mu \mathrm{g}$, respectively. The average deposition rates were between $2.11 \mathrm{E}+02$ and $4.63 \mathrm{E}+02 \mu \mathrm{g} \mathrm{s}^{-1}$.

Generally for all the samples considered, the average released concentrations, the inhaled doses, the dermal doses, and the average deposition rates values obtained were in the ranges of $1.83 \mathrm{E}+04-1.00 \mathrm{E}+06$ $\mu \mathrm{g} \mathrm{m}^{-3} ; 1.47 \mathrm{E}+03-8.01 \mathrm{E}+04 \mu \mathrm{g} ; 3.41 \mathrm{E}+04-4.84 \mathrm{E}+05$ $\mu \mathrm{g}$; and $1.79 \mathrm{E}+01-1.01 \mathrm{E}+03 \mu \mathrm{g} \mathrm{s}^{-1}$, respectively.

With reference to the ConsExpo modeling results, the average inhalation exposure from insecticides was about 1.57 folds, 2 folds, 2.83 folds, and 1.54 folds of the levels obtained from air fresheners, hairsprays, perfumes, surface and shoe impregnation sprays, respectively. Similarly, the average dermal dose from air fresheners, hairsprays, perfumes, surface and shoe impregnation sprays respectively were about $63.86 \%, 47.60 \%, 33.83 \%$ and $62.64 \%$ of the levels obtained for insecticide application. Besides, the average deposition for air fresheners, hairsprays, perfumes, surface and shoe impregnation sprays respectively were about $62.10 \%, 47.56 \%, 33.82 \%$ and $62.50 \%$ of the average rate obtained for insecticides.

Individuals might receive higher inhalation and dermal doses from insecticides spraying when compared with other household product samples used in this study. The results provide information that could be used to significantly improve human exposure and risk assessment to emitted aerosols from spray products. These results will be sufficient in calculating exposures for long time exposures but may yield an

\section{References}

Adeniran, J. A., Sonibare, J. A., \& Jimoda, L. A. (2015). Statistical approach for determining the effects of microclimatic parameters on underestimation of concentration levels for shortterm exposure duration (Bremmer et al., 2006).

\section{Conclusion}

This study investigated TVOC emission from 45 registered household spray products. Hazard ratio and ConsExpo spray model approaches were used to assess human exposure to the emitted pollutants. The results showed that high concentration levels of TVOCs were emitted from the use of spray products in the indoor environment as the average TVOC concentration from the selected samples ranged between $1,664 \mathrm{\mu g} \mathrm{m}^{-3}$ and $71,039.59 \mathrm{\mu g} \mathrm{m}^{-3}$. The ConsExpo spray model exposure assessment findings indicated that individuals receive extremely high inhalation and dermal doses from the use of spray products. Hazard ratios for the instantaneous releases of the products were the highest and pollutant concentration levels decrease with time. The HR values obtained for the instantaneous release of aerosols from the samples reached over 17 folds of the reference limit. The study observed that individuals would receive a higher dose from the use of insecticide samples. The results obtained provided relevant information that could be used to significantly improve human exposure and risk assessment to emitted aerosols from spray products.

\section{Acknowledgements}

This study was supported by Prof. Ayo Francis Ogunye Trust Fund, University of Lagos (PAFOTFUL), under the Prof. Ayo Ogunye Annual Research Fund awarded to JAA. The authors wish to acknowledge the support of the management of the University of Ilorin, Ilorin, Nigeria for providing a conducive environment for the study. Many thanks to the National Institute for Public Health and the Environment (RIVM), Netherlands, for providing the ConExpo model used in the study.

household spray products aerosol deposition. Atmospheric Pollution Research, 6(1), 21-28. https://doi.org/10.5094/APR.2015.003 
Bremmer, H., Prud'Homme de Lodder, L., \& Van Engelen, J. (2006). Cosmetics Fact Sheet. To assess the risks for the consumer. Updated version for ConsExpo 4. RIVM rapport 320104001.

Dinh, T.-V., Kim, S.-Y., Son, Y.-S., Choi, I.-Y., Park, S.-R., Sunwoo, Y., \& Kim, J.-C. (2015). Emission characteristics of VOCs emitted from consumer and commercial products and their ozone formation potential. Environmental Science and Pollution Research, 22(12), 9345-9355. https://doi.org/10.1007/s11356-015-4092-8

Erickson III, D. J., Sulzberger, B., Zepp, R. G., \& Austin, A. T. (2015). Effects of stratospheric ozone depletion, solar UV radiation, and climate change on biogeochemical cycling: interactions and feedbacks. Photochemical \& Photobiological Sciences, 14(1), 127-148. https://doi.org/10.1039/C4PP90036G

FEA. (2009). Guide on Particle Size Measurement from Aerosol Products (20090831). Retrieved from FEA aisbl - Avenue Herrmann-Debroux, 15A - 1160 Brussels - Belgium:

FEPA. (1991). Guidelines to Standards forEnvironmental Pollution Control in Nigeria. Lagos: Federal Environmental Protection Agency

Lakey, P. S., Wisthaler, A., Berkemeier, T., Mikoviny, T., Pöschl, U., $\&$ Shiraiwa, M. (2017). Chemical kinetics of multiphase reactions between ozone and human skin lipids: Implications for indoor air quality and health effects. Indoor air, 27(4), 816-828. https://doi. org/10.1111/ina.12360

Mølhave, L., \& Nielsen, G. D. (1992). Interpretation and limitations of the concept "Total volatile organic compounds"(TVOC) as an indicator of human responses to exposures of volatile organic compounds (VOC) in indoor air. Indoor air, 2(2), 65-77. https://doi. org/10.1111/j.1600-0668.1992.01-22.x

Norbäck, D., Hashim, J. H., Hashim, Z., \& Ali, F. (2017). Volatile organic compounds (VOC), formaldehyde and nitrogen dioxide (NO 2) in schools in Johor Bahru, Malaysia: Associations with rhinitis, ocular, throat and dermal symptoms, headache and fatigue. Science of the Total Environment, 592, 153-160. https://doi. org/10.1016/j.scitotenv.2017.02.215

Romonosky, D. E., Li, Y., Shiraiwa, M., Laskin, A., Laskin, J., \& Nizkorodov, S. A. (2017). Aqueous Photochemistry of Secondary Organic Aerosol of a-Pinene and a-Humulene Oxidized with Ozone, Hydroxyl Radical, and Nitrate Radical. The Journal of Physical Chemistry A, 121(6), 1298-1309. https://doi.org/10.1021/acs. jpca.6b10900

Rothe, H., Fautz, R., Gerber, E., Neumann, L., Rettinger, K., Schuh, W., \& Gronewold, C. (2011). Special aspects of cosmetic spray safety evaluations: Principles on inhalation risk assessment. Toxicology Letters, 205(2), 97-104. https://doi.org/10.1016/j. toxlet.2011.05.1038

Steinemann, A. C. (2009). Fragranced consumer products and undisclosed ingredients. Environmental Impact Assessment Review, 29(1), 32-38. https://doi.org/10.1016/j.eiar.2008.05.002

WHO. (2010). WHO guidelines for Indoor Air Quality: Selected Pollutants. Retrieved from Denmark:

Zabiegała, B. (2006). Organic Compounds in Indoor Environments. Polish Journal of Environmental Studies, 15(3), 383-393.

\section{Purškiamos buitinès chemijos poveikis aplinkai įvertinant visus lakiuosius organinius junginius}

\section{ADENIRAN, Jamiu Adetayo, YUSUF, Rafiu Olasunkanmi, MUSTAPHA, Sherif Ishola}

Aplinkos inžinerijos tyrimų laboratorija, Ilorin universiteto chemijos inžinerijos katedra, Ilorin, Nigerija

\section{SONIBARE, Jacob Ademola}

Aplinkos inžinerijos tyrimų laboratorija, Chemijos inžinerijos katedra, Obafemi Awolowo universitetas, Nigerija

Lakieji organiniai junginiai iš buitinès chemijos priemonių neigiamai veikia sveikatą ir aplinką. Tiriamajame darbe bendras lakiuju organiniu junginiu (TVOC) koncentracijos lygis nustatytas iš 45 registruotu vartotoju purškiamu buitinės chemijos produktu Nigerijoje. Buvo matuojamas naudojant MultiRAE TVOCs emisiju stebejjimo sistemą. Žmogaus ekspozicija TVOCs per ¿̨kvèpimą, nurijimą ar per odą buvo jivertinta naudojant ConsExpo purškimo modelis. Vidutine visu ištirtų mėginių TVOC emisija buvo 1,664 ir 560,994,7 $\mu \mathrm{g} \mathrm{m}^{-3}$, vidutiniškai $63,632,2 \mu \mathrm{g} \mathrm{m}^{-3}$. Visu tirtu mėginių vidutinè išleista koncentracija, ¿kvepiamos dozès, odos dozes ir vidutinis nusedimo greitis buvo $1,83 \mathrm{E}+04-1,00 \mathrm{E}+06 \mu \mathrm{g} \mathrm{m}^{-3} ; 1.47 \mathrm{E}+03-8.01 \mathrm{E}+04 \mu \mathrm{g}$; $3.41 \mathrm{E}+04-4.84 \mathrm{E}+05 \mu \mathrm{g}$; ir 1.79E + $01-1.01 \mathrm{E}+03 \mu \mathrm{g} \mathrm{s}{ }^{-1}$, atitinkamai. Rezultatuose pateikiama informacija gali būti naudojama siekiant pagerinti poveikio aplinkai ir žmoniu sveikatos vertinimą.

Raktiniai žodžiai: buitinè chemija, poveikis aplinkai, lakieji organiniai junginiai, rizikos santykis, patalpu aplinka. 